\title{
Sports potential modeling of young basketball players: a preliminary analysis
}

\section{Modelagem do potencial esportivo de jovens basquetebolistas: uma análise preliminar}

\author{
Dilson Borges Ribeiro Junior \\ Dhttps://orcid.org/0000-0002-4616-1761 \\ Jeferson Macedo Vianna \\ Dhttps://orcid.org/0000-0003-1594-4429 \\ André de Assis Lauria ${ }^{2}$ \\ (Dhttps://orcid.org/0000-0003-4296-277X \\ Emerson Filipino Coelho \\ Dhttps://orcid.org/0000-0002-0601-9672 \\ Francisco Zacaron Werneck ${ }^{3}$ \\ (Dhttps://orcid.org/0000-0003-1966-8820
}

Abstract - The aims of this study were: 1) to evaluate the sports potential of young basketball players; 2 ) to identify variables that discriminate sports potential assessed by coaches; 3 ) to verify the relationship between classification of the multidimensional profile of athletes and classification of the sports potential by coaches. Sixty-two young basketball players aged 15.6 \pm 1.1 years from $U-15(n=24)$ and $U-17(n=38)$ categories participated in the study. A test battery was applied to evaluate sports potential indicators: 1) anthropometric; 2) physicomotor; 3 ) psychological; 4) skills; 5) socio-environmental; 6) maturational and 7) sports potential. Cluster analysis was performed in three groups: high, medium and low potential. Student's t-test was used for the comparison between athletes evaluated by the coach as excellent and the others and the Chi-Square test to verify the relationship between sports potential classifications. It was observed that in the high-potential group, athletes were chronologically older, with higher $\%$ predicted adult height (PMS), competitive and determined sports orientation, higher body size, lower skinfold summation, and greater physicomotor performance. In comparison with other athletes, high-potential basketball players presented higher stature, wider wingspan, longer limb length, greater predicted adult stature and higher $Z$ score of the \% PMS. It could be concluded that the multidimensional approach was useful for the evaluation of the sports potential of young basketball players, requiring the use of multidimensional variables, in addition to coaches' opinion regarding the potential of their athletes.

Key words: Basketball; Talent identification; Sports.

Resumo - Os objetivos deste estudo foram: 1) avaliar o potencial esportivo de jovens basquetebolistas; 2) identificar variáveis que discriminam o potencial esportivo avaliado pelos treinadores; 3) verificar a relação entre a classificação do perfil multidimensional dos atletas e a classificação do potencial esportivo feita pelos treinadores. Participaram 62 jovens basquetebolistas brasileiros do sexo masculino, com 15,6 $\pm 1,1$ anos de idade, das categorias sub15 $(n=24)$ e sub17 ( $n=38)$, Foi aplicada uma bateria de testes para avaliação dos indicadores do potencial esportivo: 1) antropométricos; 2) fisicomotores; 3) psicológicos; 4) habilidades; 5) socioambientais; 6) maturacionais e 7) potencial esportivo. Foi realizada a análise de cluster classificando em 3 grupos: alto potencial, mediano e baixo potencial. Utilizou-se o teste t de Student na comparação entre os atletas avaliados pelo treinador como excelente e os demais e o teste Qui-Quadrado para testar a relação entre as classificaçôes do potencial esportivo. Observou-se que no grupo de alto potencial, os atletas eram mais velhos cronologicamente, com maior \% estatura adulta prevista, orientação esportiva competitiva e determinada, maior tamanho corporal, menor somatório de dobras cutâneas e maior desempenho fisicomotor. Na comparação com os demais atletas, os basquetebolistas de alto potencial apresentaram maior estatura, maior envergadura, maior comprimento de membros inferiores, maior estatura adulta prevista e maior escore $Z$ do \%EAP. Conclui-se que a abordagem multidimensional se mostrou útil para a avaliação do potencial esportivo de jovens basquetebolistas, sendo necessária a utilização de variáveis multidimensionais, conjugada com a opinião dos treinadores em relação ao potencial de seus atletas.

Palavras-chave: Basquetebol; Esportes; Talento esportivo.
1 Federal University of Juiz de Fora. School of Physical Education and Sports. Juiz de Fora, MG. Brazil

2 Military College of Juiz de Fora. Juiz de Fora, MG. Brazil

3 Federal University of Ouro Preto. Ouro Preto, MG. Brazil

Received: October 20, 2018 Accepted: April 09, 2019

How to cite this article Ribeiro Junior DB, Vianna JM, Lauria AA, Coelho EF, Werneck FZ. Sports potential modeling of young basketball players: a preliminary analysis. Rev Bras Cineantropom Desempenho Hum 2019, 21:e59832. Dol: http://dx.doi. org/10.1590/1980-0037.2019v21e59832.

Copyright: This work is licensed under a Creative Commons Attribution 4.0 International License. 


\section{INTRODUCTION}

Athletic performance in basketball depends on a diversity of individual characteristics, including body size and composition, fitness and technical and tactical skills, as well as psychological attributes ${ }^{1}$. Identifying young people who present the best combination of these qualities and selecting those with great potential to become future athletes has been a challenge for researchers and coaches ${ }^{2-4}$.

Scientific evidence has shown that sports talent is identifiable ${ }^{5}$, and that elite performance depends on the combination of genetics, training, and environmental factors ${ }^{3,6}$. Traditionally, sports potential evaluation has been performed through the opinion of coaches $^{7}$ and application of test batteries $^{8}$, being essential to combine practical experience and scientific knowledge.

In young basketball players, studies have shown the usefulness of test batteries for the identification of potential talents ${ }^{9-11}$. Body size and physical fitness, for example, may contribute to the selection of young athletes, but the predictive capacity of these indicators alone is $\operatorname{low}^{8,9}$. On the other hand, evaluation performed by coaches has been one of the main predictors, explaining from 56 to $86 \%$ performance variability among young basketball players ${ }^{9}$. However, agreement between classifications of athletes performed by test batteries and coaches needs to be better investigated ${ }^{10,11}$. When the coaches' opinion is combined with objective and reliable data, measured through test batteries, the percentage can reach $80 \%^{12}$.

In this sense, the current understanding is that multidimensional and dynamic approach must be used to assess sports potential and select athletes ${ }^{2,3,13}$. For this, different multivariate statistical techniques such as discriminant analysis ${ }^{13,14}$, cluster analysis ${ }^{15-18}$, multiple linear regression ${ }^{9,10}$, multilevel regression models ${ }^{12}$ and artificial neural networks ${ }^{14}$ have been used for a better understanding of performance-relevant factors, classification of athletes and prediction of potential for certain modalities. Some authors have developed intelligent systems by means of statistical modeling in order to estimate the sports potential of young athletes ${ }^{19}$ and even to guide players to game positions with greater probability of success ${ }^{20}$.

In Brazil, there are propositions of sports potential modeling in schoolchildren $^{21}$ and young soccer players ${ }^{22}$. The basic assumption of the sports potential modeling is that young people who present the highest number of requirements necessary for good performance in one modality are likely to have greater chance of success ${ }^{19}$. Considering the lack of a model for the identification of sports talents in Brazilian basketball, the aims of this preliminary study were: 1) to evaluate the sporting potential of young basketball players, adopting multidimensional approach; 2) to identify variables that discriminate sports potential assessed by coaches; 3 ) to verify the relationship between classification of the multidimensional profile of athletes and classification of sports potential performed by coaches. 


\section{METHOD}

\section{Sample}

Sixty-two Brazilian male basketball players aged $15.6 \pm 1.1$ years from $\mathrm{U}-15(\mathrm{n}=24)$ and $\mathrm{U}-17(\mathrm{n}=38)$ categories, with at least 12 months of systematic practice in basketball clubs of the city of Juiz de Fora, Minas Gerais, inserted in competitions of regional and state level participated in the study. This study is part of the "Projeto Atletas de Ouro: Multidimensional and Longitudinal Evaluation of the Sports Potential of Young Athletes" ${ }^{21}$, approved by the Ethics Research Committee of the Federal University of Ouro Preto (CAAE: 32959814.4.1001.5150). Consent from legal guardians and athletes were obtained before participating in the study.

\section{Instruments and Procedures}

Athletes were submitted to a test battery to evaluate the following performance factors: 1) anthropometric; 2) physicomotor; 3) psychological; 4) skills; 5) socio-environmental; 6) maturational and 7) sports potential.

\section{Anthropometric Indicators}

Measurements of body mass, height, wingspan, sitting height and three skinfolds (triceps, subscapular and leg) were performed. A digital anthropometric scale was used to measure body mass. Height was measured through a tape measure attached to the wall. To measure height, a square-shaped device was used. For sitting height measurement, portable stadiometer (Sany, Brazil) was used with a coupled bench, so that the individual kept hips flexed at a $90^{\circ}$ angle. The length of lower limbs was estimated from the difference between standing height and seated height. Skinfold measurements were obtained using calibrated scientific adipometer (Sany, Brazil).

\section{Physicomotor Indicators}

Flexibility assessment was performed through the sit and reach test using the Whels bank (Sany, Brazil). Muscle power of lower limbs was evaluated through the countermovement jump test (CMJ) using a contact mat (Multi-Sprint Full ${ }^{\circledR}$, Hidrofit, Brazil). To evaluate the muscle power of the upper limbs, the medicine-ball throw test with $2-\mathrm{kg}$ ball was used. To evaluate the maximum isometric strength of hands, the handgrip strength test was performed using manual dynamometer $\left(\operatorname{Jamar}^{\circledR}\right)$. The displacement velocity was evaluated by the 10 and $20 \mathrm{~m}$ speed test with maximum sprint, measured by photoelectric cell system (Multi-Sprint Full ${ }^{\circledR}$, Hidrofit, Brazil). For anaerobic evaluation, the Line Drill test was used, which consists of running $140 \mathrm{~m}$ as fast as possible in the form of four consecutive sprints of 5.8, 14.0, 22.2 and $28.0 \mathrm{~m}$ within a basketball court ${ }^{13}$.

\section{Psychological Indicators}

To evaluate the competitive profile of athletes, the Sports Orientation Questionnaire ${ }^{23}$ was used, which enabled classifying the athletes' behavior as 
competitor, determined and winner. The Athletic Coping Skills Inventory 28 in its Portuguese version (ACSI-28BR $)^{24}$ was used for coping evaluation. For the evaluation of the orientation to goals, the Questionnaire of Sports Guidance for Task or Ego was used ${ }^{25}$. To assess the athletes' perceived competence, the following questions were used: 1 ) "Considering the factors involved in basketball, how do you rate your current performance?”; 2) “How do you rate your performance in basketball compared to other athletes who compete with you?". Athletes answered questions on a Likert-type scale (1-Weak, 2-Reasonable, 3-Good, 4-Very Good, 5-Excellent).

\section{Skill Indicators}

To evaluate specific motor skill of basketball, the dribble control test with changes of direction was used ${ }^{26}$. Tactical Skills Inventory for Sports (TACSIS) in its Portuguese version was used to evaluate tactical skills ${ }^{27}$. It has four sub-scales: positioning and decision, knowledge about actions with ball, knowledge about others and action in changing situations, in addition to the sum of scales.

\section{Socio-environmental Indicators}

To evaluate family support, factor 1 of IFATE $^{28}$ was used. In the sports experience evaluation, information on age of beginning in the sport and practice time was collected (date of collection - age of beginning).

\section{Maturational Indicators}

Biological maturation was evaluated through somatic maturation indicators: 1) percentage of predicted adult stature (\% PMS);2) predicted age at peak height velocity (age at PHV). Predicted adult height was estimated by the relation of chronological age, actual height and body mass, in addition to the height of biological parents ${ }^{29}$. Maturational indicator \% PMS was then calculated by the following equation: \% PMS = (current height $/$ predicted adult height) * 100 . The higher the \% PMS, the closer the individual will be from the mature stage (adult). Based on reference data by age group and sex, the $\mathrm{Z}$ scores were calculated to obtain maturational stage classifications into late, on time or early. The predicted age at $\mathrm{PHV}$ was estimated by means of sex-specific prediction equations based on chronological age and anthropometric measures, maturity offset $(\mathrm{MO})$ was calculated, which represents the distance in years that the individual is from PHV. The maturational indicator age at $\mathrm{PHV}$ was then estimated by the following equation: Age at $P H V=$ current chronological age $-(-1 * M O)^{30}$. Negative values indicate that individuals have not yet reached $\mathrm{PHV}$, while positive values indicate that they have already reached $\mathrm{PHV}$.

\section{Sports Potential Evaluated by Coaches}

Coaches were questioned in the sense of assigning a subjective classification relative to the expectation of success of each of their athletes. They were asked to evaluate the potential for future performance of each of the 
players in the following classification system: 1-Weak; 2- Reasonable; 3-Good; 4-Very good; 5-Excellent ${ }^{9}$.

\section{Statistical analysis}

Data were described by mean \pm standard deviation. Cluster analysis was performed using the non-hierarchical K-means method, aiming at classifying young athletes into three groups (high potential, medium potential and low potential). This multivariate statistical model aims to classify athletes based on the measured variables, grouping them in such a way that they have characteristics similar to each other within the group in which they were classified and are heterogeneous compared to the other groups ${ }^{17}$. The Student $t$ test was used in the comparison between athletes evaluated by the coach as high potential (Excellent) and the other athletes. The comparison between sports potential classifications made by tests and coaches was performed by the Chi-Square test. All analyses were performed on IBM SPSS software version 24.0 (IBM Corp., Armonk, NY). P $\leq 0.05$ was adopted for statistical significance.

\section{RESULTS}

Table 1 presents the classifications obtained through cluster analysis. The values presented represent the midpoints (centroids) of the sports potential indicators evaluated. For the interpretation of results, the highest values obtained in the measured indicators were used as criterion, classifying seven athletes with low potential, 27 with medium potential and 16 with high potential. Based on the centroid of groups and analysis of variance, it was observed that in the high potential group, athletes were chronologically older, with higher \% PMS and greater predicted adult height, competitive and determined sports orientation, larger body size, smaller skinfold summation and greater physicomotor performance. No differences were observed between groups in time of practice and family support, perceived competence, maturational stage, technical and tactical skills and in the other psychological variables.

Coaches classified 19 athletes as low potential (weak and reasonable), 20 as median potential (good and very good) and eight as high potential (excellent). In comparison with the other athletes, high potential basketball players $(n=8)$ presented higher stature, wingspan, longer lower limbs, greater predicted adult height and higher $\mathrm{Z}$ score of \% PAH - Table 2. Statistically significant association was observed between sports potential classification performed by coaches and the maturational stage of athletes $\left(\mathrm{X}^{2}=7.723, \mathrm{p}=0.021\right)$, with higher prevalence of maturationally advanced athletes classified as high sports potential and higher proportion of athletes classified as low potential among normal maturation athletes, Figure 1. There was no relationship between classification performed by coaches and that of the multidimensional profile $\left(\mathrm{X}^{2}=0.952, \mathrm{p}=0.91\right)$. The overall percentage agreement was 39\% - Figure 2. 
Table 1. Classification of the sport potentials of young basketball players using cluster analysis and respective mean values (centroids) of each variable measured.

\begin{tabular}{|c|c|c|c|c|c|}
\hline Variables & $\begin{array}{c}\text { Cluster } \\
\text { Low Potential } \\
(n=7)\end{array}$ & $\begin{array}{c}\text { Cluster } \\
\text { Median Potential } \\
(n=27)\end{array}$ & $\begin{array}{c}\text { Cluster } \\
\text { High Potential } \\
\text { (16) }\end{array}$ & $F$ & $p$-value \\
\hline Age (years) & 15.3 & 15.1 & 16.1 & 4.56 & $0.01^{\star}$ \\
\hline Body Mass (kg) & 86.3 & 59.4 & 76.4 & 46.71 & $<0.001^{*}$ \\
\hline Height (cm) & 181.2 & 171.4 & 185.7 & 28.027 & $<0.001^{*}$ \\
\hline Length mmii (cm) & 88.5 & 83.1 & 91.5 & 20.016 & $<0.001^{*}$ \\
\hline Wingspan (cm) & 186.0 & 175.4 & 193.4 & 24.993 & $<0.001^{*}$ \\
\hline$\Sigma$ Skinfolds (mm) & 71.4 & 32.4 & 35.7 & 76.209 & $<0.001^{*}$ \\
\hline MO & 2.13 & 1.10 & 2.55 & 16.112 & $<0.001^{*}$ \\
\hline Age at PHV (years) & 13.2 & 14.0 & 13.6 & 6.674 & $0.003^{*}$ \\
\hline$\%$ РAH & 97.7 & 96.2 & 99.1 & 7.218 & $0.002^{*}$ \\
\hline Z Score $\%$ PAH & .99 & .73 & .92 & 1.288 & 0.28 \\
\hline PAH & 13.2 & 14.0 & 13.6 & 6.674 & $0.003^{*}$ \\
\hline Practice time (years) & 2.34 & 2.69 & 2.69 & 0.152 & 0.86 \\
\hline Family support & 26.1 & 25.6 & 27.2 & 0.227 & 0.80 \\
\hline Perceived Competence & 5.6 & 6.5 & 7.0 & 1.525 & 0.23 \\
\hline Competitor & 54.9 & 55.4 & 61.4 & 3.703 & $0.03^{*}$ \\
\hline Winner & 26.4 & 22.7 & 24.4 & 1.310 & 0.28 \\
\hline Determined & 26.6 & 26.0 & 29.8 & 3.265 & $0.047^{\star}$ \\
\hline Ego orientation & 1.86 & 2.25 & 2.41 & 1.141 & 0.32 \\
\hline Task orientation & 4.10 & 4.33 & 4.54 & 1.270 & 0.29 \\
\hline Coping & 12.11 & 13.03 & 13.28 & 0.456 & 0.64 \\
\hline Handgrip strength & 35.6 & 30.9 & 41.6 & 9.098 & $<0.001^{*}$ \\
\hline Medicine ball throw (m) & 4.90 & 4.65 & 5.86 & 8.480 & $0.001^{*}$ \\
\hline Sit and reach $(\mathrm{cm})$ & 20.9 & 23.0 & 28.5 & 2.720 & 0.08 \\
\hline CMJ (cm) & 24.8 & 31.6 & 36.1 & 9.154 & $<0.001^{*}$ \\
\hline Speed $10 \mathrm{~m}(\mathrm{~s})$ & 2.01 & 1.898 & 1.794 & 11.589 & $<0.001^{*}$ \\
\hline Speed $20 \mathrm{~m}$ (s) & 3.54 & 3.301 & 3.102 & 13.678 & $<0.001^{*}$ \\
\hline Line Drill (s) & 34.10 & 31.887 & 30.581 & 4.715 & $0.01^{*}$ \\
\hline Dribbling Skill (s) & 9.28 & 9.038 & 8.658 & 1.271 & 0.29 \\
\hline Tactical Skills & 2.01 & 3.97 & 4.08 & 2.024 & 0.14 \\
\hline
\end{tabular}

Note. (mmii): lower limbs, SF: skinfolds - triceps, subscapularis and leg, CMJ: countermovement jump, $\%$ PAH: percentage of predicted mature stature, MO: maturity offset, PHV: peak height velocity ${ }^{*}$ statistically significant difference significant, $p<0.05$ ).

Table 2. Comparison of the univariate profile of young basketball players classified by coaches regarding the sport potential.

\begin{tabular}{llll}
\hline Variables & $\begin{array}{l}\text { Low/Median Potential } \\
(\mathrm{n}=43)\end{array}$ & $\begin{array}{l}\text { High Potential } \\
(\mathrm{n}=8)\end{array}$ & -value \\
\hline Age (years) & $15.75 \pm 1.15$ & $15.51 \pm 1.49$ & 0.60 \\
Body Mass $(\mathrm{kg})$ & $68.79 \pm 13.42$ & $71.27 \pm 10.70$ & 0.62 \\
Height $(\mathrm{cm})$ & $175.84 \pm 9.16$ & $183.25 \pm 9.7651$ & $0.04^{*}$ \\
Length mmii $(\mathrm{cm})$ & $85.08 \pm 5.18$ & $91.04 \pm 5.39$ & $0.01^{*}$ \\
Wingspan $(\mathrm{cm})$ & $179.37 \pm 10.69$ & $190.60 \pm 12.24$ & $0.01^{*}$ \\
$\Sigma$ Skinfolds $(\mathrm{mm})$ & $40.29 \pm 16.18$ & $38.75 \pm 13.35$ & 0.80 \\
M0 & $1.8472 \pm 1.12$ & $1.96 \pm 1.36$ & 0.80
\end{tabular}

Continue... 
... continue

\begin{tabular}{llll}
\hline Variables & $\begin{array}{l}\text { Low/Median Potential } \\
(\mathrm{n}=43)\end{array}$ & $\begin{array}{l}\text { High Potential } \\
(\mathrm{n}=8)\end{array}$ & p-value \\
\hline Age at PHV (years) & $13.90 \pm 0.78$ & $13.54 \pm 0.65$ & 0.23 \\
\% PAH & $97.69 \pm 2.22$ & $97.90 \pm 2.85$ & 0.82 \\
Z Score \% PAH & $0.74 \pm 0.44$ & $1.14 \pm 0.31$ & $0.02^{*}$ \\
PAH & $180.20 \pm 7.39$ & $187.13 \pm 7.24$ & $0.02^{*}$ \\
Practice time (years) & $3.05 \pm 2.63$ & $2.01 \pm 1.35$ & 0.28 \\
Family support & $26.00 \pm 6.72$ & $28.00 \pm 7.28$ & 0.45 \\
Perceived Competence & $6.14 \pm 2.04$ & $6.62 \pm 1.7$ & 0.53 \\
Competitor & $55.66 \pm 8.40$ & $56.50 \pm 7.65$ & 0.80 \\
Winner & $23.66 \pm 6.31$ & $22.87 \pm 4.01$ & 0.73 \\
Determined & $26.31 \pm 3.21$ & $27.00 \pm 4.07$ & 0.60 \\
Ego orientation & $2.13 \pm 0.97$ & $2.14 \pm 0.68$ & 0.97 \\
Task orientation & $4.14 \pm 1.14$ & $4.37 \pm 0.47$ & 0.58 \\
Coping & $12.57 \pm 2.77$ & $13.50 \pm 2.50$ & 0.38 \\
Handgrip strength & $34.64 \pm 9.59$ & $39.12 \pm 7.14$ & 0.22 \\
Medicine ball throw (m) & $5.09 \pm 1.06$ & $4.90 \pm 0.95$ & 0.63 \\
Sit and reach (cm) & $23.82 \pm 8.97$ & $27.44 \pm 9.92$ & 0.31 \\
CMJ (cm) & $32.18 \pm 6.90$ & $33.55 \pm 8.42$ & 0.62 \\
Speed 10m (s) & $1.88 \pm 0.13$ & $1.86 \pm 0.11$ & 0.60 \\
Speed 20m (s) & $3.28 \pm 0.25$ & $3.25 \pm 0.18$ & 0.73 \\
Line Drill (s) & $31.94 \pm 2.66$ & $31.56 \pm 2.97$ & 0.72 \\
Dribbling Skill (s) & $8.94 \pm 0.84$ & $9.03 \pm 1.34$ & 0.80 \\
Tactical Skills & $4.15 \pm 0.71$ & $3.72 \pm 1.11$ & 0.16 \\
\hline & & & \\
\hline
\end{tabular}

Note. (mmii): lower limbs, SF: skinfolds - triceps, subscapularis and leg, CMJ: countermovement jump,\% PAH: percentage of predicted mature stature, MO: maturity offset, PHV: peak height velocity ${ }^{*}$ statistically significant difference significant, $p<0.05$ ).

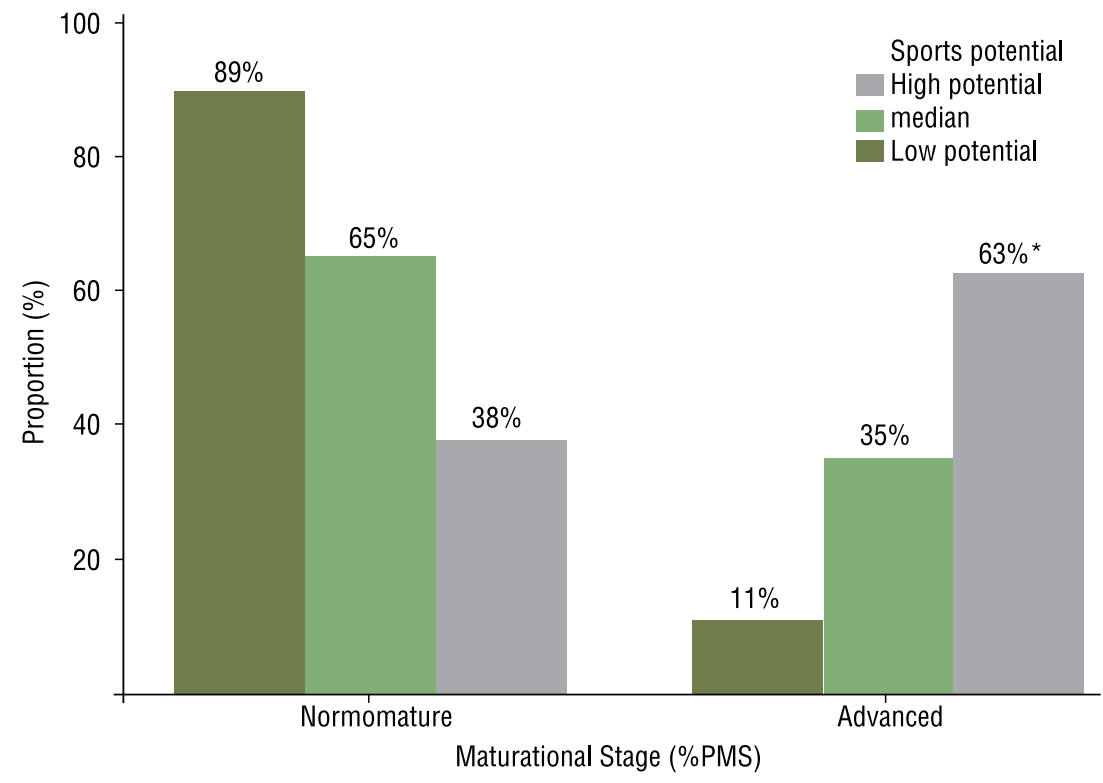

Figure 1. Relationship between sports potential classification performed by coaches and maturational stage of young basketball players evaluated by the percentage of predicted mature stature (\%PMS). ( ${ }^{*}$ Significant difference, $\left.p<0.05\right)$. 


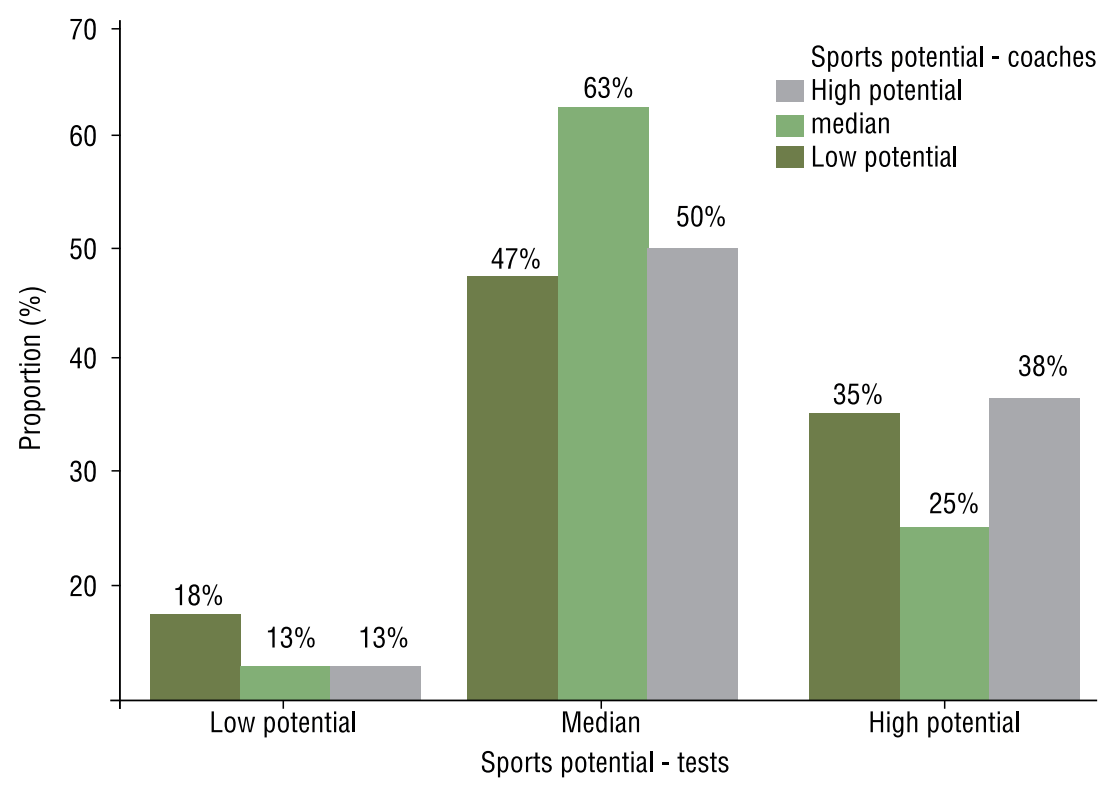

Figure 2. Agreement between sports potential classification of young basketball players performed by tests and coaches ( ${ }^{*}$ Non-significant difference, $p>0.05$ ).

\section{DISCUSSION}

The results of the present study confirmed the premise that the sports potential of young basketball players should be evaluated in a multidimensional way, based on the different performance indicators, objectively measured by means of test batteries, together with the coaches' opinion. In addition, it was observed that the sports potential evaluated by coaches privileges athletes with larger body size and biologically more advanced.

The sports potential classification of young athletes through multivariate techniques, such as cluster analysis, has aroused the interest of several researchers ${ }^{14-18}$. The use of multivariate statistical techniques allows the establishment of non-linear relationships between the various evaluations, presenting better capacity for the generalization of results, increasing the quality of the evaluation. One of the major research issues concerns how statistical models are able to effectively predict the likelihood of a young athlete being successful in a particular sport.

Current models attempt to measure performance determinants by adequately measuring biological maturation and sport experience, systematically and over time. However, available evidence shows that its predictive capacity is low ${ }^{3}$.

There is evidence that the prognosis of the performance of young athletes is feasible and maximizes investments of time and resources ${ }^{12}$. The premise of models is that certain profiles are associated with better performances, so that young athletes who present higher number of characteristics required for good performance in the sport will probably have greater chance of success ${ }^{19}$.

There is scientific evidence that the results obtained in test batteries for young athletes are able to predict sport success. Young people with 
above-average performance in tests tend to be the most successful in the future $^{16}$ and diagnosis using test batteries has shown greater prognostic capacity compared to coach's opinion ${ }^{30}$. In Switzerland, for example, a recent longitudinal study with young soccer players aged $12-15$ years found that the most promising ones are not necessarily the best, but rather those who present above-average performance in physicomotor and skill tests consistently over the years, with emphasis on a holistic perspective in the selection of talents, that is, person-oriented ${ }^{16}$.

However, the available longitudinal studies are insufficient to conclude that anthropometric and physicomotor indicators have acceptable levels of accuracy for the detection of young talents ${ }^{3}$. Anthropometric, physicomotor and skill tests can be used to assess the sports potential, orientation to modalities more adequate to a given profile, monitoring the training effects and also the prediction of the future success of young athletes in different sports modalities, since integrated into a systematic and longitudinal development process. Thus, tests should serve as a prerequisite assessment ${ }^{5}$, which from results can direct the youngster to modalities in which he is supposed to be more likely to be successful and, mainly, a support for the development of a talent over the training process.

The use of classification techniques has presented satisfactory results for the guidance of young athletes to different modalities or game positions within the same modality. In basketball, discriminant analysis presented $92 \%$ agreement in the classification of the positions of players into point guard, shooting guard, small forward, power forward and center. The application of proposed position-specific performance profiles, determined by predictive classification models, can help coaches put the right player in the right place on the basketball court ${ }^{14}$.

In addition to variables related to physical fitness and technical skills, the present study revealed the importance of taking into account psychological skills in the evaluation of young athletes. Our results corroborate the available literature, which points to intrinsic motivation, persistence, dedication, determination, emotional stability, self-regulation and focus on competition as precursors of sports talent ${ }^{5}$. The strength of evidence found for these characteristics for the identification and development of talents is moderate to high ${ }^{3}$.

Corroborating previous studies, an important relationship was observed between sports potential evaluated by coaches and the biological maturation of young basketball players ${ }^{7,8}$. In young Australian soccer players, it was found that the coach's perception of the long-term sports potential was biased by the biological variability of athletes in favor of those more biologically advanced ${ }^{7}$. In this sense, coaches should be aware that selection in the child-youth sport tends to have a maturational gradient, privileging those more biologically advanced, which present advantages, most of times temporary, in relation to the others. The evaluation of biological maturation minimizes the risk of mistaken judgments and errors in the selection process, as well as the early exclusion of young talented athletes ${ }^{8}$. Therefore, 
it is important to emphasize that the evaluation of biological maturation should be considered, but new opportunities for the test and selection of younger and late maturation athletes should be given.

There was no relationship between sports potential classification performed by the cluster analysis and that performed by coaches, unlike findings of previous studies ${ }^{10,17}$. During the selection process of young Australian basketball players using a battery of anthropometric, motors and technical tests, Hoare ${ }^{10}$ found that modeling based on $\mathrm{Z}$-score was able to explain $40 \%$ variance in athletes' performance, with $60 \%$ agreement between classification obtained in the tests and the coaches' opinion. In addition to the small sample size of the present study, which implies greater probability of sample error, a possible explanation for this result is that tests measure the present phenotype (current performance), while coaches try to estimate the future phenotype (success potential).

In fact, the small sample size is the main limitation of this study, requiring caution in the interpretation of results. It was not the purpose of this study to create a standard method for the identification of basketball talents, but to provide information that can guide the process of identifying and developing new talents, offering support in the decisions of coaches. Other multivariate statistical techniques and analysis by age group should be explored to better understand the sports potential of young athletes. In addition, further studies should evaluate the sports potential dynamics, that is, how it evolves throughout the training process.

\section{CONCLUSION}

It was concluded that the multidimensional approach through the application of test batteries and subjective evaluation by coaches was useful in assessing the sports potential of young basketball players. Coaches should avoid hasty judgments in the diagnosis and selection of their athletes, especially because they tend to give more value to larger, more biologically advanced athletes. The low agreement between classifications performed by tests and coaches suggests that they should be used in a combined way for a better understanding of the athletic potential of young basketball players.

\section{Acknowledgments}

We would like to thank the Graduate Program in Physical Education of the Federal University of Juiz de Fora, financial support form the Federal University of Ouro Preto, public notice 006/2016-PIP-2S/UFOP. The Logistical support of the Military School of juiz de Fora - EME Cooperation Agreement 18-055-00 and the financial support by means of parliamentary amendment 36820009 PLN 0020/2017-LOA.

\section{COMPLIANCE WITH ETHICAL STANDARDS}

\section{Funding}

This research did not receive any specific grant from funding agencies in the 
public, commercial, or non-profit sectors. This study was funded by the authors.

\section{Ethical approval}

This study is an integral part of the "Projeto Atletas de Ouro: Multidimensional and Longitudinal Evaluation of Young Athletes' Sports Potential”, approved by the Research Ethics Committee of the Federal University of Ouro Preto (CAAE: 3295814.4.1001.5150).

\section{Conflict of interest statement}

The authors have no conflict of interests to declare.

\section{Author Contributions}

Conceived and designed the experiments: DBRJ; FZW; EFC; AAL and JMV. Performed the experiments: DBRJ; FZW; EFC; AAL and JMV. Analyzed data: FZW. Contributed with reagents/materials/analysis tools: DBRJ; AAL; FZW; EFC and JMV. Wrote the paper: DBRJ; AAL; FZW; EFC and JMV.

\section{REFERENCES}

1. Drinkwater EJ, Pyne DB, And Mckenna MJ. Design and Interpretation of Anthropometric and Fitness Testing of Basketball Players. Sports Med 2008;38(7):565-578.

2. Buekers M, Borry P. \& Rowe P. Talent in sports. Some reflections about the search for future champions. Mov Sport Sci 2014;(1)1-10.

3. Rees T, Hardy L, Gullich A, Et Al. The Great British medalists project: A review of current knowledge on the development of the world's best sporting talent. Sports Med 2016;46(8):1041-1058.

4. Brown J. Sports talent: how to identify and develop outstanding athletes. Human Kinetics, Champaign, IL; 2001.

5. Issurin VB. Evidence-based prerequisites and precursors of athletic talent: a review. Sports Med 2017;47(10):1993-2010.

6. Tucker R, Collins M. What makes champions? A review of the relative contribution of genes and training to sporting success. Br J Sports Med 2012;(9):05-48.

7. Cripps AJ, Hopper LS, Joyce C. Coaches' perceptions of long-term potential are biased by maturational variation. Int J Sports Sci Coach 2016;11(4)478-481.

8. Pearson DT, Naughton GA, Torode M. Predictability of physiological testing and the role of maturation in talent identification for adolescent team sports. J Sci Med Sport 2006;9(4):277-287.

9. Hoffman JR, Tenenbaum CM, Maresh, Kraemer WS. Relationship between athletic performance tests and playing time in elite college basketball players. J Strength Cond Res 1996;10(02):67-71.

10. Hoare DG. Predicting success in junior elite basketball players - the contribution of anthropometric and physiological attributes. J Sci Med Sport 2000;3(4):391-405.

11. Drinkwater E, Hopkins WG, Mckenna MJ, Hunt PH, Pyne DB. Modelling age and secular differences in fitness between basketball players. J Sports Sci 2007;25(8):869-878.

12. Pion J, Segers V, Fransen J, Debuyck G, Deprez D, Haerens L, Vaeyens R, et al. Generic anthropometric and performance characteristics among elite adolescent boys in nine different sports. Eur J Sport Sci 2014;15(5):357-366.

13. Carvalho HM, Gonçalves CE, Collins D, Paes RR (2017). Growth, functional capacities and motivation for achievement and competitiveness in youth basketball: an interdisciplinary approach. J Sports Sci 2017;36(7):742-748. 
14. Pion J, Segers V, Fransen J, Debuyck G, Deprez D, Haerens L, Vaeyens R, et al. Generic anthropometric and performance characteristics among elite adolescent boys in nine different sports. Eur J Sport Sci 2015;15(5):357-366.

15. Pion J, Segers V, Stautemas J, Boone J, Lenoir M, Borgois Jg. P. Position-specific performance profiles, using predictive classification models in senior basketball. Int J Sports Sci Coach 2018;1-9.

16. Zhang S, Lorenzo A, Gómez MA, Mateus N, Gonçalves B, Sampaio J. Clustering performances in the NBA according to players' anthropometric attributes and playing experience. J Sports Sci 2018;1-10.

17. Zuber C, Zibung M, Conzelmann A. Holistic Patterns as an Instrument for Predicting the Performance of Promising Young Soccer Players - A 3-Years Longitudinal Study. Front Psychol 2016;7:10-88.

18. Paes, F.O.; Uezu R; Massa M; Bohme, Mts. Classificação e seleção de jovens atletas através da análise de cluster. J Phys Education 2008;19(3):369-375.

19. Zuber C, Zibung M, Conzelmann A. Motivational patterns as an instrument for predicting success in promising young football players. J Sports Sci 2014; 1-9.

20. Papić V, Rogulj N, Pleština V. Identification of sport talents using a web-oriented expert system with a fuzzy module. Exp Systems App 2009;36(5):8830-8838.

21. Dezman B, Trninic S, Dizdar D. Expert model of decision-making system for eficiente orientation of basketball players to positions and roles in the game-empirical verification. Coll Antropol 2001;25(1):141-152.

22. Werneck FZ, Ferreira RM, Coelho EF, Sobreira DI, Miranda L, Figueiredo AJB, et al. Projeto Atletas de Ouro: Validade e estabilidade do diagnóstico do potencial esportivo em escolares de um colégio militar. J Phys Education 2017;86(2):140-142.

23. Werneck FZ, Coelho EF, Matta MO, De Paula HLB, Ferreira RM, Figueiredo AJB. Modelagem do potencial esportivo de jovens futebolistas: um estudo preliminar. Rev Bras Futebol. Anais do 6ºSoccer Experience 2017.

24. Gallegos SSO, Massucato JG, Simões AC, Prouvot PA Yoshikawa RMS. Competitividade e performance esportiva em tenistas profissionais. Rev Paul Educ Fís 2002;16(2):144-159.

25. Miranda R, Coimbra DR, Bara Filho MG, Miranda Junior MV, Andrade A. Brazilian version (ACSI-28BR) of athletic coping skills inventory-28. Rev Bras Med Esporte 2018;(24)2:130-134.

26. Hirota VB. Motivação para aprendizagem esportiva no futebol de campo: um estudo com o questionário de orientação para tarefa ou ego (TEOSQ). [Dissertação de Mestrado-Facis]; Piracicaba (SP): Unimep, 2006.

27. Kirkendall D, Gruber J, Johnson R. Measurement and Evaluation for Physical Educators. Champaign, IL Human Kinetics; 1987.

28. Ribeiro Junior DB, Elferink Genser MT, Valente Dos Anjos J, Figueiredo AJ, Furtado GE, Coelho e Silva MJ. Tactical skills inventory for sports in youth basketball: Portuguese version and extraction of the 4-factors structure (Abstract). 19 Annual Congress of European College of Sports Science 2014;438.

29. Silva PVC; Fleith, DS. Fatores familiares associados ao desenvolvimento do talento no esporte. Rev Bras Psicol Esporte 2010;3(4):19-40.

30. Khamis HJ, Roche AF. Predicting adult stature without using skeletal age: the Khamis-Roche method. Pediatrics 1994;94(4):504-507.

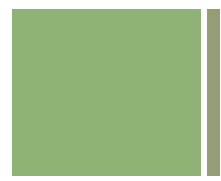

Corresponding author

Dilson Borges Ribeiro Junior

Avenida Senhor dos Passos, 2102/13

CEP: 36037-490, São Pedro, Juiz de Fora/MG, Brazil

Email: dilsonborges@hotmail.com 